Article

\title{
Area-Based Approach for Mapping and Monitoring Riverine Vegetation Using Mobile Laser Scanning
}

\author{
Ninni Saarinen ${ }^{1,2, *}$, Mikko Vastaranta ${ }^{2}$, Matti Vaaja ${ }^{3}$, Eliisa Lotsari ${ }^{1}$, Anttoni Jaakkola ${ }^{4}$, \\ Antero Kukko ${ }^{4}$, Harri Kaartinen ${ }^{4}$, Markus Holopainen ${ }^{2}$, Hannu Hyyppä ${ }^{3,5}$ and Petteri Alho ${ }^{1,3}$ \\ 1 Department of Geography and Geology, University of Turku, FI-20014 Turku, Finland; \\ E-Mails: eliisa.lotsari@uef.fi (E.L.); petteri.alho@utu.fi (P.A.) \\ 2 Department of Forest Sciences, University of Helsinki, FI-00014 Helsinki, Finland; \\ E-Mails: mikko.vastaranta@helsinki.fi (M.V.); markus.holopainen@helsinki.fi (M.H.) \\ 3 Department of Real Estate, Planning and Geoinformatics, Aalto University, FI-00076 Aalto, \\ Finland; E-Mail: matti.t.vaaja@aalto.fi \\ 4 Department of Remote Sensing and Photogrammetry, Finnish Geodetic Institute, FI-02431 Masala, \\ Finland; E-Mails: anttoni.jaakkola@fgi.fi (A.J.); antero.kukko@fgi.fi (A.K.); \\ harri.kaartinen@fgi.fi (H.K.) \\ 5 Helsinki Metropolia University of Applied Sciences, FI-00079 Helsinki, Finland; \\ E-Mail: hannu.hyyppa@metropolia.fi \\ * Author to whom correspondence should be addressed; E-Mail: ninni.saarinen@helsinki.fi; \\ Tel.: +358-40-516-8461.
}

Received: 6 September 2013; in revised form: 16 October 2013 / Accepted: 16 October 2013 /

Published: 22 October 2013

\begin{abstract}
Vegetation plays an important role in stabilizing the soil and decreasing fluvial erosion. In certain cases, vegetation increases the accumulation of fine sediments. Efficient and accurate methods are required for mapping and monitoring changes in the fluvial environment. Here, we develop an area-based approach for mapping and monitoring the vegetation structure along a river channel. First, a $2 \times 2 \mathrm{~m}$ grid was placed over the study area. Metrics describing vegetation density and height were derived from mobile laser-scanning (MLS) data and used to predict the variables in the nearest-neighbor (NN) estimations. The training data were obtained from aerial images. The vegetation cover type was classified into the following four classes: bare ground, field layer, shrub layer, and canopy layer. Multi-temporal MLS data sets were applied to the change detection of riverine vegetation. This approach successfully classified vegetation cover with an overall classification accuracy of $72.6 \%$; classification accuracies for bare ground, field layer,
\end{abstract}


shrub layer, and canopy layer were $79.5 \%, 35.0 \%, 45.2 \%$ and $100.0 \%$, respectively. Vegetation changes were detected primarily in outer river bends. These results proved that our approach was suitable for mapping riverine vegetation.

Keywords: LiDAR; mobile laser scanning (MLS); riverine environment; river bank; vegetation; change detection

\section{Introduction}

One of the most effective methods to prevent soil erosion is to increase vegetative cover on the land, because vegetative cover prevents both wind and water erosion [1]. In a riverine environment, vegetation acts as an interface between the flowing water and the soil. The plant roots bind the soil, interweave with other roots, and form a solid network permeating the soil, which increases the resistance to erosion. The removal of vegetation increases the rate of surface erosion [2]. During flood events, river bends lacking riparian vegetation can experience up to five times greater erosion than vegetated bends, and non-vegetated banks may experience up to ten times greater erosion than vegetated banks [3]. Thus, mapping and monitoring of riverside vegetation provides important information for understanding river channel evolution, fluvial modeling, and erosion-risk mapping.

Laser scanning (LS) enables an accurate three-dimensional characterization of the vertical structure of vegetation [4]. Airborne laser scanning (ALS) has proven to be an information-rich asset for mapping of vegetation characteristics because it accurately derives information on vegetation height and density [5,6]. ALS enables the generation of highly detailed digital terrain models (DTMs) and the estimation of a range of vegetation attributes [7]. Terrestrial laser scanning (TLS) applications are used to estimate more detailed characteristics of vegetation. For example, ALS can be used to map the aboveground biomass over large areas of forest $[8,9]$, whereas TLS can be used to describe the quality of individual tree trunks $[10,11]$.

ALS measurements of a riverine environment have recently enabled estimations of mass wasting and bank erosion from large areas and long river reaches [12,13]. Mobile laser scanning (MLS) and TLS have been used successfully for very detailed mapping and monitoring of riverine topography [14-18]. Alho et al. [19] reported the first use of an MLS system with a laser scanner mounted on a boat. This approach facilitated an effective survey angle for mapping the vegetation in deep riverbank topographies, which are difficult to map with ALS or TLS [16,19]. Although the accuracy of boat-based MLS is less than that of TLS, Vaaja et al. [16] showed that MLS can provide accurate and precise change information over larger areas of riverine topography. Boat-based MLS also provides a cost-effective alternative to small-scale vegetation mapping with ALS data. ALS provides information about tree height and density of a tree crown whereas MLS provides information about the properties and quality of vegetation. However, area-wide vegetation mapping with boat-based MLS is challenging because data coverage may not be continuous compared to that for airborne sensors. The major drawback is that vegetation located in blind spots (i.e., shadowed by other vegetation or rock overhangs) cannot be measured. MLS systems have reasonable accuracy and utility for many environmental applications [20-25]. 
The riverbank characteristics of soil properties, length of rainfall periods, matric suction, geometry, and vegetation cover play important roles in bank failure and erosion-risk assessment [1,26-29]. Millar [30] showed that bank vegetation also exerts significant control over alluvial channel patterns. Vegetation also affects soil moisture and stability, freeze-thaw cycling, and erosion, especially in cohesive soils [31-33]. The growth rate and reproduction of vegetation in riverine environments responds to and affects fluvial processes by adapting to stream-flow variations, erosion, and burial stresses [34]. Flow disturbance has an effect on riparian vegetation [35] but established vegetation hinders erosion and increases the stability of deposition stream banks [36]. Bank-erosion processes are complicated in cold climatic conditions; accurate mapping and monitoring of riverside vegetation provides important information for understanding these processes.

Hydrodynamic, morphodynamic, bank-erosion, and channel-migration models of river environments also benefit from information on vegetation cover because they require estimations of channel roughness and bank strength that are caused by channel material and vegetation [37-39]. These models can be used to determine flood inundation areas, flood risk management, river management, and river rehabilitation [38,40-43]. DTM is the essential input data for hydrodynamic and morphodynamic modeling and fluvial geomorphological studies [18,19,44-46]. The inclusion of detailed information on vegetation cover and its yearly stability improves the model simulation results [34]. MLS is suitable for accurate DTM generation in a riverine environment because of its efficient survey angle for steep riverbanks $[16,19,47]$. Thus, it is advantageous to use MLS for mapping vegetation in addition to terrain topography.

Only a few MLS-based mapping and change-detection studies have been published [48]. To date, the use of MLS for mapping is limited primarily to corridors (e.g., road, stream, or river) with limited spatial extent, such as roadside mapping [49-53]. Wang et al. [54] used MLS data to detect and model sediment particles in fluvial systems. Forest mapping using MLS is challenging [55-57]. In fluvial studies, the proximity of the area of interest (riverine vegetation on the banks) to the mapping trajectory (river) ensures that data coverage is sufficient for mapping. Important riverine vegetation characteristics to map are vegetation type, vegetation coverage, and changes in vegetation. ALS and TLS have been used to classify riverine vegetation [58-60]. However, MLS has not been widely used for vegetation mapping. Because MLS can generate accurate DTMs, it is necessary to test if MLS data can be used for mapping and tracing changes in vegetation in a riverine environment.

The aim of this study was to develop a nearest-neighbor (NN) approach for mapping and monitoring riverine vegetation. The approach required grid-level training data and MLS data to derive DTMs and vegetation metrics. The mapping was tested for a four-class classification scheme, in which the classes varied from bare ground to canopy layer. Multi-temporal MLS data from 2009 to 2012 were used for monitoring vegetation changes.

\section{Materials and Methods}

\subsection{Study Area}

The study area is located on the meandering Pulmanki River (Figure 1), which is a 58-km tributary of the sub-arctic River Tenojoki (Tana). The Pulmanki River flows across the border of Finland and 
Norway at latitude $69.95^{\circ} \mathrm{N}$ and longitude $28.10^{\circ} \mathrm{E}$, where Lake Pulmanki divides the river into two parts. The river has eroded a channel $30 \mathrm{~m}$ deep and 20-50 $\mathrm{m}$ wide. The river is characterized by steep banks (Figure 2), is highly sensitive to erosion and has large point bars. Snowmelt causes spring floods, whereas the water level is lowest and point bars are maximally exposed in the late summer. During snowmelt and the spring flood period, the water level can be several meters higher than the level in low-flow periods during summer and autumn. A flood flow causes remarkable sediment transport, including heavy erosion and deposition along the riverbanks and point bars.

Figure 1. Illustrations of the study area. (A) The Pulmanki River is located in northern Finland. (B) The Pulmanki River is part of the River Tenojoki (Tana) drainage basin. (C) The scanned reach of the Pulmanki River is $3.5 \mathrm{~km}$ in length.
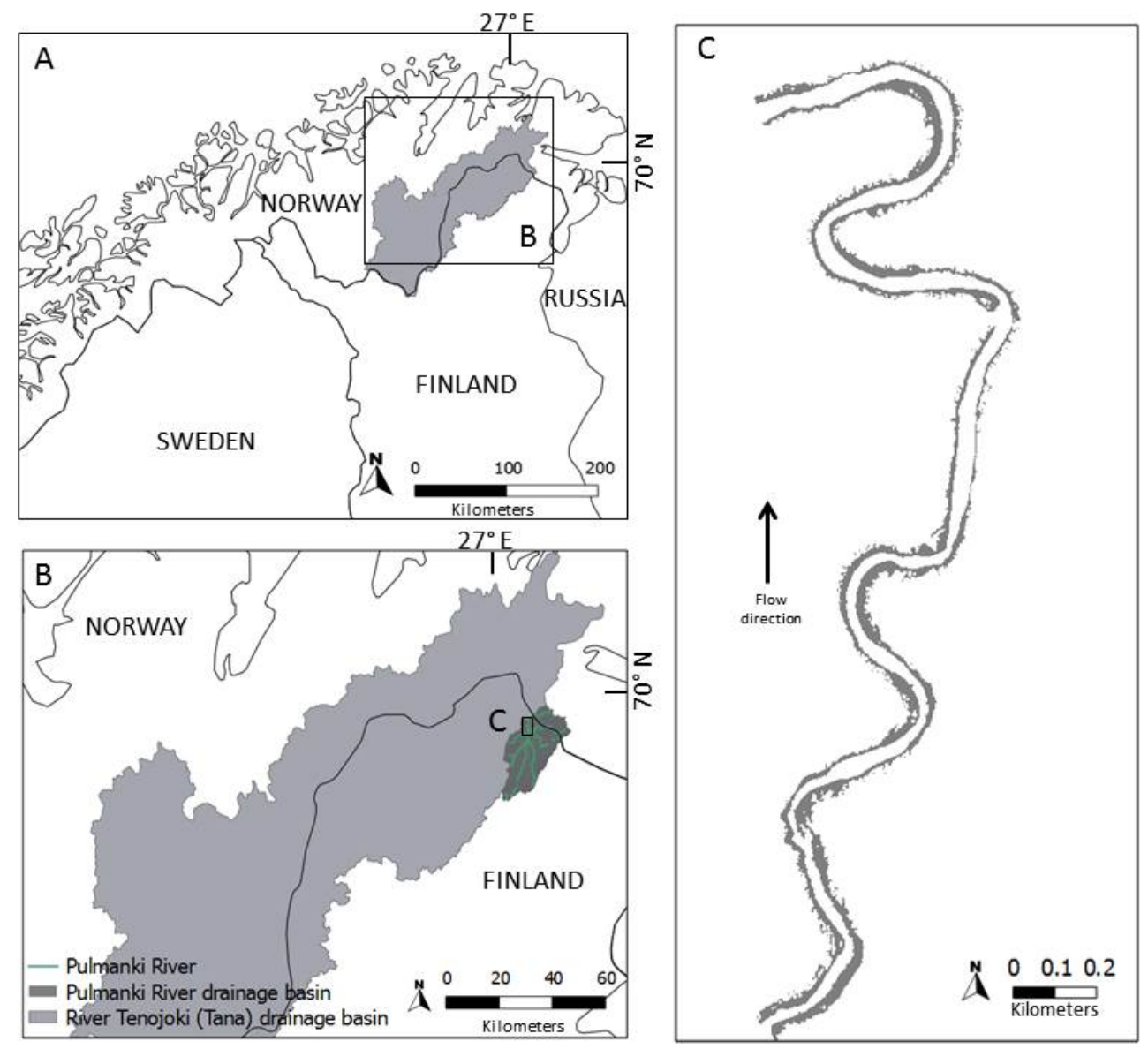

Figure 2. Representative riverbank of the Pulmanki River. The flow direction is from right to left.

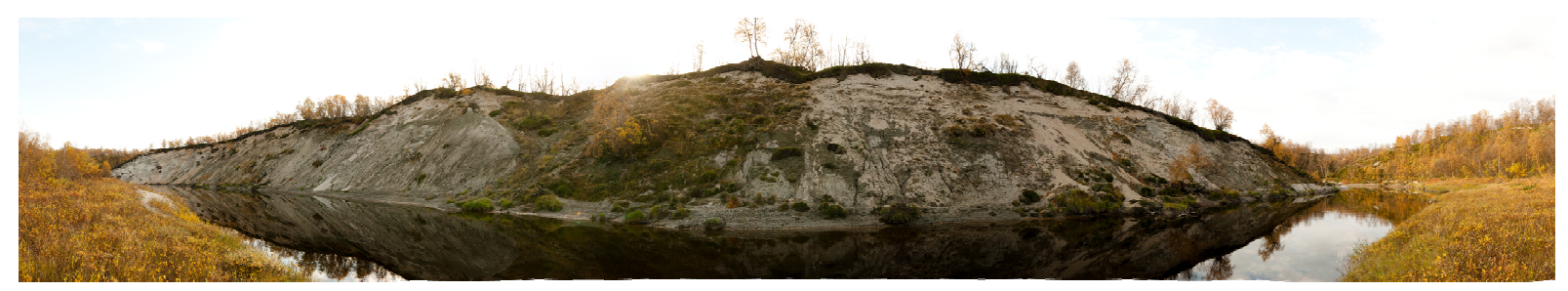




\subsection{Mobile Laser Scanning Data}

MLS data were acquired to measure riverine topography and characterize vegetation. We acquired MLS data from the study area in late summer (late August to early September) of 2009, 2010, 2011, and 2012. We used the ROAMER- mobile mapping system (MMS), which has been in development by the Finnish Geodetic Institute [19,61]. ROAMER MMS utilizes the FARO Photon 120 (or the FARO Photon 80 for previous ROAMER version which was used in 2009 data acquisition) terrestrial laser scanner to acquire three-dimensional (3D) measurements. The FARO Photon 120 achieves maximum mapping range of $120 \mathrm{~m}$, measurement rate of $120-976 \mathrm{kHz}$, field-of-view of $320^{\circ}$, and beam divergence of $0.16 \mathrm{mrad}$. The system parameters used each year are summarized in Table 1 . The navigation solution for the MMS is generated by the NovAtel Synchronized Position Attitude Navigation (SPAN) technology, which integrates GPS and inertial data for applications that require greater functionality and reliability than traditional stand-alone GPS is capable of offering. The SPAN system also operates in real-time kinematic mode with an internet-based application, named vDiff, which is developed by the Finnish Geodetic Institute [61]. The GPS receiver is a NovAtel DL-4plus containing an OEMG2 engine, and a GPS-702 antenna that offers access to the GPS L1 and L2 frequencies. The inertial measurement unit (IMU) is a tactical-grade, ring-laser gyro-based unit manufactured by Honeywell. The laser-acquired point data were geo-referenced during post-processing using raw laser-scanning data, laser-scanning trajectory data, and synchronization data. Waypoint Inertial Explorer software was used to compute laser-scanning trajectory, combining IMU and GPS data logged by the SPAN and data logged at the GPS reference station on the site. Under good conditions, the elevation accuracy of the ROAMER point cloud is better than $3.5 \mathrm{~cm}$ up to a range of $35 \mathrm{~m}$, and the planimetric accuracy is better than $5 \mathrm{~cm}$ with a range of $45 \mathrm{~m}$ [62].

Table 1. System parameters for the mobile laser scanning acquisitions at different time points $\left(f_{s}=\right.$ scanning frequency, $f_{p}=$ point measurement frequency, $h_{s}=$ sensor altitude from the water surface, and $r_{a}=$ angular resolution).

\begin{tabular}{cccccc}
\hline & Date & $\mathbf{f}_{\mathbf{s}}(\mathbf{H z})$ & $\mathbf{f}_{\mathbf{p}}(\mathbf{k H z})$ & $\mathbf{h}_{\mathbf{s}}(\mathbf{m})$ & $\mathbf{r}_{\mathbf{a}}\left(^{\circ}\right)$ \\
\hline 2009 & 3 September & 30 & 120 & 2.5 & 0.090 \\
2010 & 31 August & 49 & 244 & 2.5 & 0.072 \\
2011 & 8 September & 49 & 244 & 2.5 & 0.072 \\
2012 & 13 September & 49 & 488 & 2.5 & 0.036 \\
\hline
\end{tabular}

\subsection{Aerial Images}

Aerial images were acquired using an unmanned aerial vehicle (UAV) helicopter to provide additional information on vegetation. The images were taken in 2012 at the same time as MLS data were acquired. The images were taken with a Samsung NX1000 micro-DSLR camera equipped with a $16 \mathrm{~mm}$ F2.4 lens mounted onboard a T-Rex 700E RC helicopter. As the UAV helicopter was controlled manually, the flying altitude varied, with most of the images taken between 20 and $70 \mathrm{~m}$ above ground level, and with an average flying altitude of $47 \mathrm{~m}$. A total of 1,687 images from six flights were used in the production of the orthophoto, which was generated using the Agisoft 
PhotoScan software. The images were geo-referenced with 84 signals or spherical targets placed around the target area, and the accuracy of the bundle adjustment was $7.3 \mathrm{~cm}$.

\subsection{Filtering and Generation of Digital Terrain Models}

MLS data were used to derive vegetation points and DTMs for 2009-2012. Because we used a phase-based approach, the number of false points is higher than that in pulse-based systems. In particular, there were noise points with low reflectivity and density in the air and below ground. We filtered the point clouds using the intensity and point-density values. The appropriate thresholds were determined for each year from test samples, and then we performed filtering for the entire dataset. The intensity thresholds varied from 500 to 700 (scale 0-2,044). The density-based method computes the number of points within a certain radius in the air, and removes the points if the density is less than the threshold. The applied threshold varied between test years with a value of 10 or 15 points within a spherical radius of $30-50 \mathrm{~cm}$.

Ground-point classification was performed according to the method developed by Axelsson [63]. The method classified terrain points by iteratively building a triangulated surface model. Classification started by selecting some seed points that were confident hits on the ground within a user-defined grid (we used a $20 \mathrm{~m}$ grid). Seed points were selected to form an initial model. For each iteration of the model, one point at a time was added if it was below a user-defined parameter threshold value. Parameters were the maximum distance from a point to the triangle plane and the maximum angle between a point, as well as its projection on the triangle plane and the closest triangle vertex. A distance of $20 \mathrm{~cm}$ and an angle of $25^{\circ}$ were used in this study. The iterative process ended when there were no more points below the threshold.

DTMs were formed from the classified ground points using a regular grid approach. We created separate, regular grids with $20 \mathrm{~cm}$ point spacing from each year's data, and we calculated the model elevation as an average elevation of the ground points within the $20 \times 20 \mathrm{~cm}$ grid cell area. The ground-point density was $100-1,000$ points $/ \mathrm{m}^{2}$ on the non-vegetated point bars. The root-mean-square error (RMSE) of the MLS-based DTMs for non-vegetated point bars ranged between 3.0 and $4.2 \mathrm{~cm}$ after correction of the systematic error. The ground-point determination for densely vegetated bank areas was more difficult, and resulted in RMSE between 12.6 and $28.5 \mathrm{~cm}$ [64]. The mapping distance of the MLS system depended on terrain topography, system trajectory, and vegetation. DTMs derived from the MLS acquisitions in the Pulmanki reach were $14.4 \mathrm{~m}$ wide on average, with minimum, maximum, and standard deviations of $2.5,32.6$, and $8.1 \mathrm{~m}$, respectively.

\subsection{Extraction of Metrics from $M L S$}

Vegetation was characterized using metrics derived from the MLS point clouds (see Section 2.4). A $2 \times 2 \mathrm{~m}$ grid was selected to provide sufficiently detailed MLS points for calculating the metrics, and the grid was placed over the study area. If insufficient information was acquired to generate DTMs in some areas (e.g., areas covered by water) the metrics were not calculated for those cells. Twenty MLS-derived metrics describing vegetation height and density were calculated for every grid cell using FUSION software [65]. The generated DTMs were used to normalize vegetation heights to the height above ground. The calculated metrics are presented in Table 2. 
Table 2. Metrics calculated from MLS data.

\begin{tabular}{cc}
\hline Metric & Description \\
\hline TotalReturn & Total number of laser returns \\
$H_{\min }$ & Minimum height of laser returns \\
$H_{\max }$ & Maximum height of laser returns \\
$H_{\text {mean }}$ & Arithmetic mean of laser heights \\
$H_{\text {std }}$ & Standard deviation of laser heights \\
$H 1-H 99$ & Percentiles of laser heights \\
\hline
\end{tabular}

\subsection{Vegetation Classes}

Vegetation classes for 230 training grid cells were classified using expert knowledge and visual inspection of aerial images. Training cells were selected systematically over the study area to include approximately equal samples from each vegetation class. Vegetation was classified according to a common woodland sequence structure in Finnish forests. Areas that lacked vegetation were called bare ground. The field layer was composed of grasses, ferns, and low growing shrubs, (e.g., blueberry (Vaccinium myrtillus) and heather (Calluna vulgaris)). The shrub layer contained small trees and larger shrubs. The canopy layer contained the dominant tree canopy. Vegetation classes are shown in Figure 3 . A second testing set of 212 grid cells was selected to evaluate the mapping accuracy.

Figure 3. Illustration of vegetation classes selected from aerial images. Note the submerged and dry areas of the meander bend. Coordinates of the corners of the capture are presented in ETRS89/ETRS-TM35FIN.

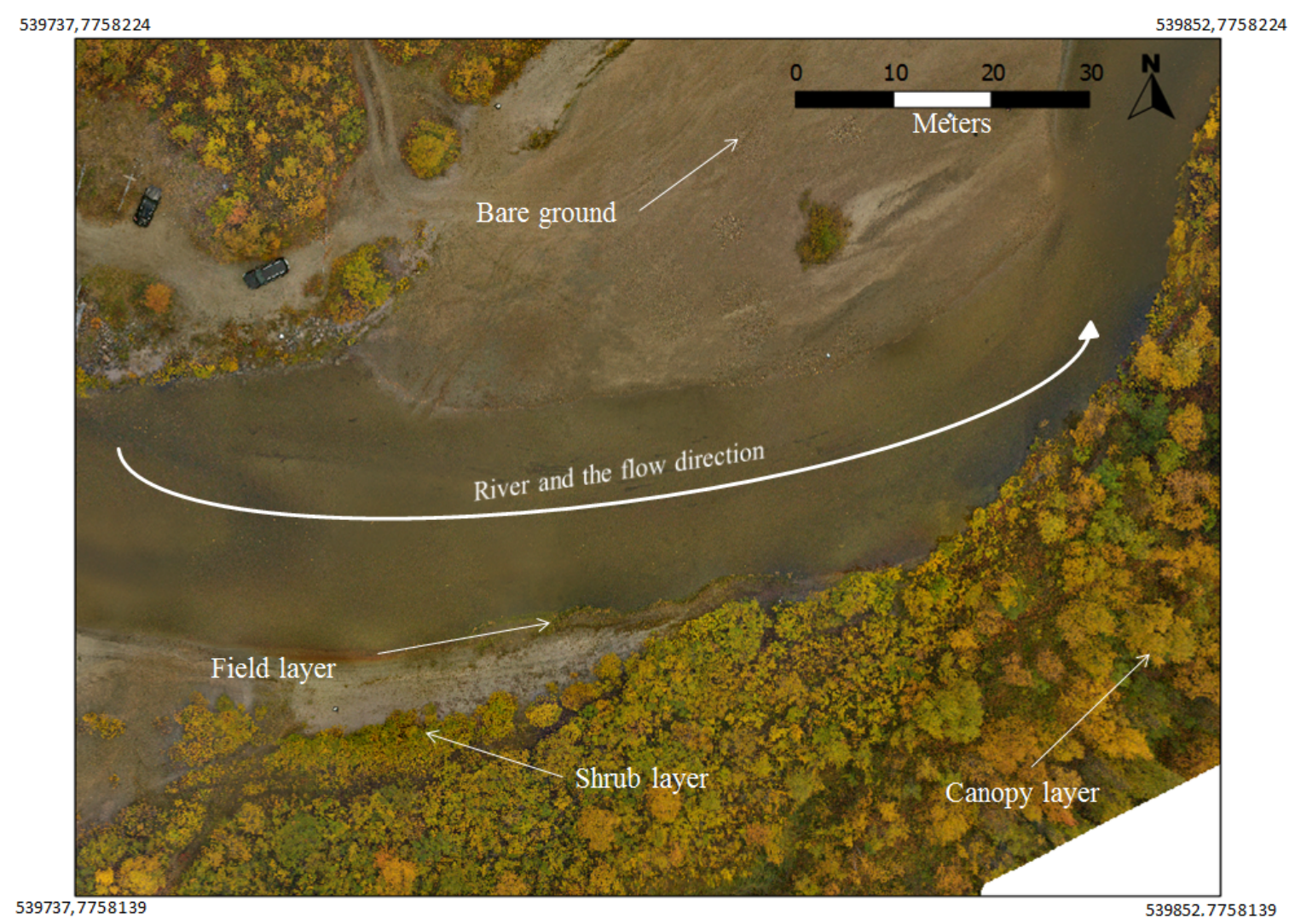




\subsection{Classification of Vegetation Using the Area-Based Approach}

This approach used nearest-neighbor estimation in which nearest neighbors were selected based on the similarities of the MLS metrics. The area-based prediction of vegetation was based on a statistical dependency between the variables measured from the aerial photos and predictor features derived from MLS data. This kind of two-stage procedure to produce information from wall-to-wall grid-level predictions was called an area-based approach [5].

The vegetation classes determined visually from the aerial images were used as the target observations ( $y$-values), and the metrics calculated from MLS data were used as predictors ( $x$-values). The predictors were chosen based on biological relevance and previous experience. Vegetation classes should be separable based on height and vertical density using a $2 \times 2 \mathrm{~m}$ grid as an interpretation unit. Therefore, grid cells with mean height and 95th percentile height were used. Maximum height of MLS point was not used because it is sensitive to single errors in point heights. Standard deviations of the vegetation heights also were used to describe vegetation height and density, and it is also robust to single erroneous points.

The Random Forests (RF) method was used for the NN search as explained in detail by Crookston and Finley [66]. In the RF method, several regression or classification trees are generated by drawing a replacement of two-thirds of the data for training and one-third for testing each tree (i.e., out-of-the-bag samples). A regression tree is a sequence of rules that splits the feature space into partitions that have values similar to the response variable. Measurement of nearness in RF is defined based on observations of the probability of ending up in the same terminal node during classification. The output is the percentage increase in misclassification rate as compared to that of the out-of-bag rate (with all variables intact). The number of nearest neighbors (parameter $k$ ) was chosen to be five based on previous knowledge. A total of 1,000 regression trees were in each RF run to gain increased consistency.

The classification results were validated using the RF out-of-the-bag samples and an independent testing data set (see Section 2.6). The RF model that was trained with the 2012 data also was used to predict vegetation classes in 2009, 2010, and 2011.

\section{Results}

\subsection{Accuracy of Mapping Vegetation}

Classification of vegetation cover was based on mean height $\left(H_{\text {mean }}\right)$, standard deviation of height $\left(H_{s t d}\right)$, and 95th-percentile height $(H 95)$ calculated from MLS point clouds. The classification metrics differed among the four vegetation classes within the grid cells that were used to train the RF classification from year 2012. This result indicated that classes could be separated using these MLS metrics. The differences between the vegetation classes for the mean values of $H_{\text {mean }}, H 95$, and $H_{s t d}$ were all statistically significant using the Student's $t$-test $(p<0.001)$. For bare ground, $H_{\text {mean }}$ was $0.01 \mathrm{~m}$ on average. The respective mean values for field layer, shrub layer, and canopy layer were 0.7 , 0.52 , and $2.52 \mathrm{~m}$ (Figure 4). Mean values increased gradually from bare ground to the canopy layer.

For bare ground, field layer, shrub layer, and canopy layer, the $H 95$ mean values were $0.02,0.20,1.19$, and $5.59 \mathrm{~m}$, respectively, and the $H_{\text {std }}$ mean values were $0.01,0.07,0.40$, and $1.90 \mathrm{~m}$, respectively. 
Figure 4. Variations of $H_{\text {mean }}, H_{\text {std }}$ and $H 95$ within each vegetation class (derived from data collected in 2012).
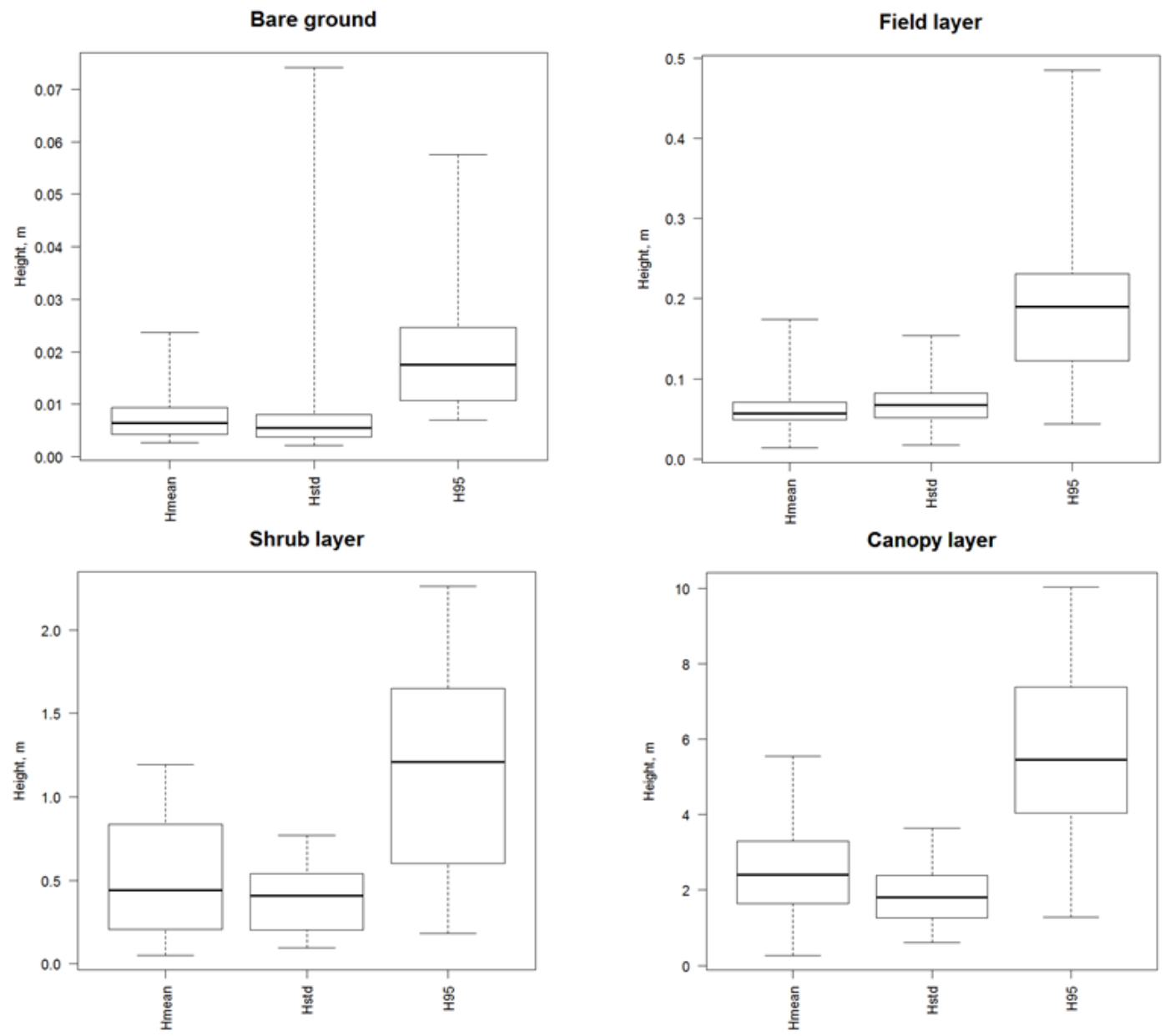

Vegetation cover was classified using the NN approach with overall classification accuracy of $72.6 \%$ in our test data set. Classification accuracies for bare ground, field layer, shrub layer, and canopy layer were $79.5 \%, 35.0 \%, 45.2 \%$, and $100.0 \%$, respectively. Classification accuracies for the training and testing data sets are presented in Table 3. The predicted vegetation map for 2012 is presented in Figure 5.

Table 3. Accuracy of vegetation classification.

\begin{tabular}{ccccc}
\hline & Training Accuracy (\%) & Testing Accuracy (\%) & Kappa Training & Kappa Testing \\
\hline Bare Ground & 100.00 & 79.45 & 0.99 & 0.82 \\
Field Layer & 88.00 & 35.00 & 0.91 & 0.39 \\
Shrub Layer & 97.83 & 45.16 & 0.93 & 0.29 \\
Canopy Layer & 97.40 & 100.00 & 0.98 & 0.72 \\
Average & 97.39 & 72.64 & 0.96 & 0.61 \\
\hline
\end{tabular}

Cross-tabulation showed that the canopy layer was classified most accurately $(97.4 \%-100.0 \%)$. The shrub layer was classified as the canopy layer in $7.6 \%$ of cases. The shrub layer also was misclassified as the field layer. The field layer was classified as shrub layer in $7.6 \%$ of cases and as canopy layer in 
$4.3 \%$ of cases. Bare ground was classified as field layer, shrub layer and canopy layer in 1.9, 3.8 and $1.4 \%$ of cases, respectively (Table 4). Bare ground was misclassified as vegetated areas in $20.5 \%$ of cases and vegetated areas were misclassified as bare ground in $0.7 \%$ of cases.

Figure 5. Vegetation estimations for the area covered by aerial images in 2012 (left) with close capture of the downstream section of area A (right). Coordinates of the captures are presented in ETRS89/ETRS-TM35FIN.

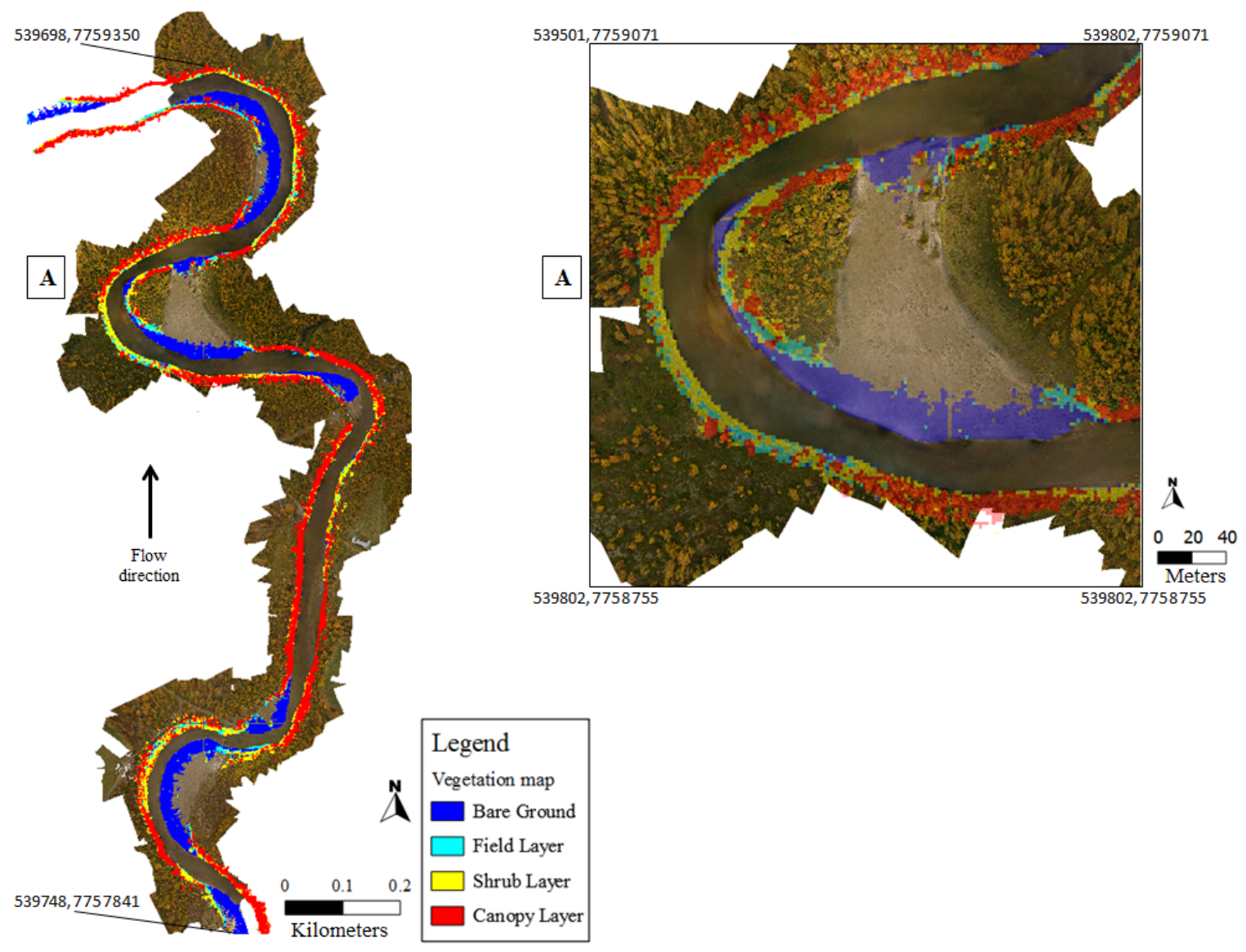

Table 4. Cross-tabulation of vegetation classes using a test set $(n=212)$, with true classes in the vertical axis and estimated classes in the horizontal axis.

\begin{tabular}{cccccc}
\hline True/Estimated & Bare Ground & Field Layer & Shrub Layer & Canopy Layer & Total \\
\hline Bare Ground & 58 & 4 & 8 & 3 & 73 \\
Field Layer & 1 & 14 & 16 & 9 & 40 \\
Shrub Layer & 0 & 1 & 14 & 16 & 31 \\
Canopy Layer & 0 & 0 & 0 & 68 & 68 \\
\hline
\end{tabular}

\subsection{Monitoring Vegetation Structure}

We derived vegetation estimations for 2009, 2010, 2011, and 2012. Vegetation estimations for the study area are presented in Figures 5 (2012) and 6 (2009-2012). Mapping was based on an RF model created with data collected in 2012. Changes in vegetation classes are presented in Figure 7. There were some variations in the amount of change from year to year. For years 2009-2010, 2010-2011, 
and 2011-2012, there were changes in $25.0 \%, 25.2 \%$ and $21.2 \%$ of the study area, respectively. The changes occurring in these areas were categorized as negative (erosion or damage) or positive (vegetative growth). For the $25 \%$ of changed area during 2009-2010 negative and positive changes were detected in $24.2 \%$ and $75.8 \%$ of the area, respectively. For the $25.2 \%$ of changed area during 2010-2011, negative and positive changes were detected in 55.4\% and $44.6 \%$ of the area, respectively. For the $21.2 \%$ of changed area during 2011-2012, negative and positive changes were detected in $39.0 \%$ and $61.0 \%$ of the changed area, respectively. Changes were detected throughout the study area, including the meander bends and the straight channel sections.

Figure 6. Vegetation estimations for years 2009-2012. Coordinates of the north and south reach of the research area are presented in ETRS89/ETRS-TM35FIN.
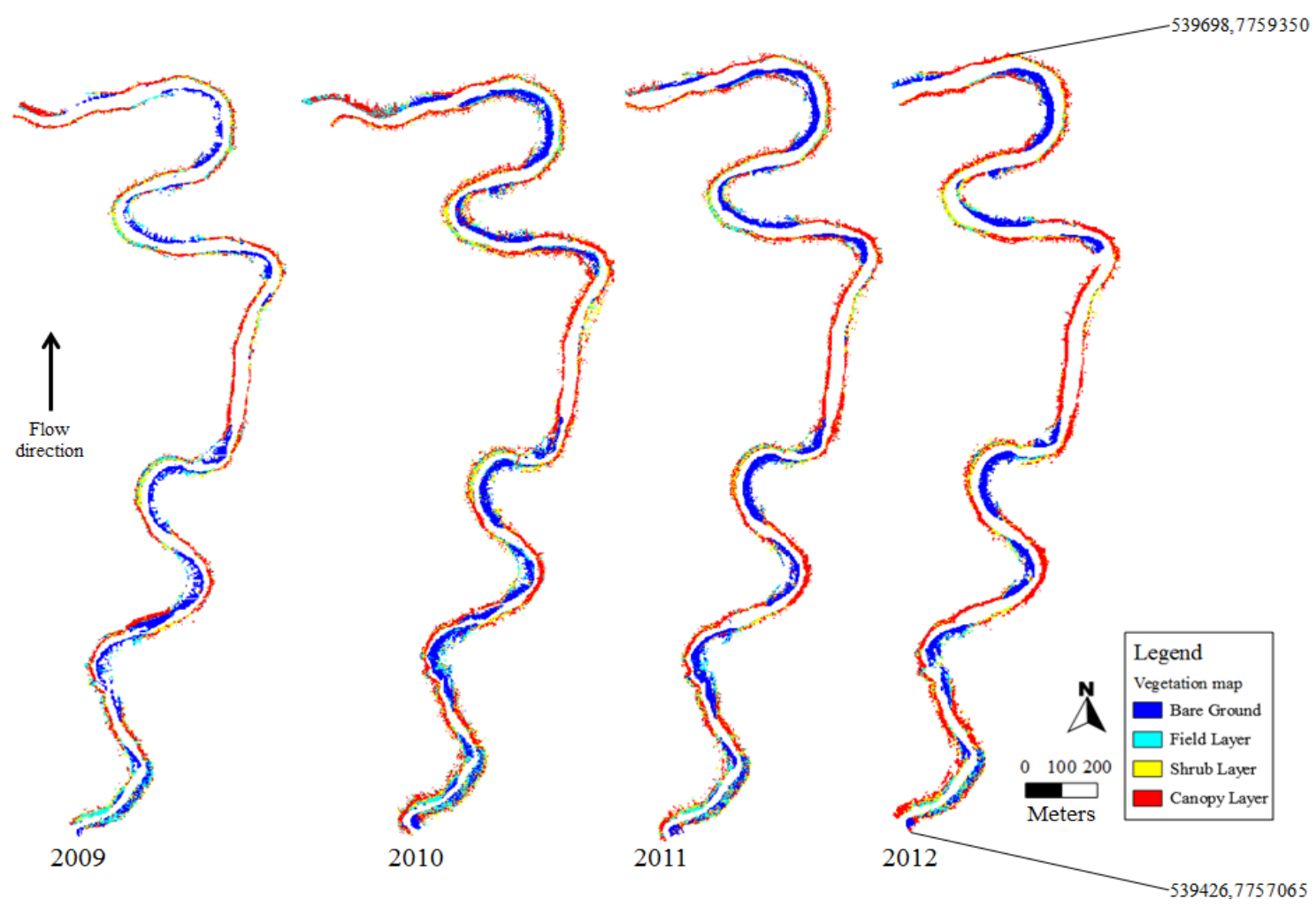

\section{Discussion}

The next generation of riverine models is anticipated to require information on riverbank vegetation required. Current bank-erosion models have options for inserting vegetation parameters and root strength into simulations [38]. For the purposes of river management and flood analysis [67,68], hydrodynamic or rainfall-runoff models require roughness estimates, which originate from bank and flood-plain vegetation. It has been difficult to perform detailed and fast mapping of riverbank vegetation cover on vertical banks. Although vegetation is an important determinant of the evolution of river channels and riverbanks, some modeling studies still do not fully consider vegetation in riverine environments [69]. Capture of vegetation classes and changes in vegetation will allow for the incorporation of variables for erosion rates into models. These state-of-the-art models can more accurately predict river dynamics, can easily solve river-management issues, and can deepen our 
understanding of bank-erosion processes. The results of the current study provide new information regarding how MLS data can be used for mapping and monitoring riverbank vegetation. Although several MLS features were calculated for use as possible predictors, the only predictors with sufficient information and robustness were mean height, standard deviation, and 95 percentile of height. A mapping accuracy of $72.6 \%$ was obtained. We found that it was useful to use the same MLS data acquired for DTM generation for the extraction of information for the vegetation cover.

Figure 7. Changes in vegetation classes associated with erosion or damage (negative change) and vegetative growth (positive change) in different years. Coordinates of the north and south reach of the research area are presented in ETRS89/ETRS-TM35FIN.

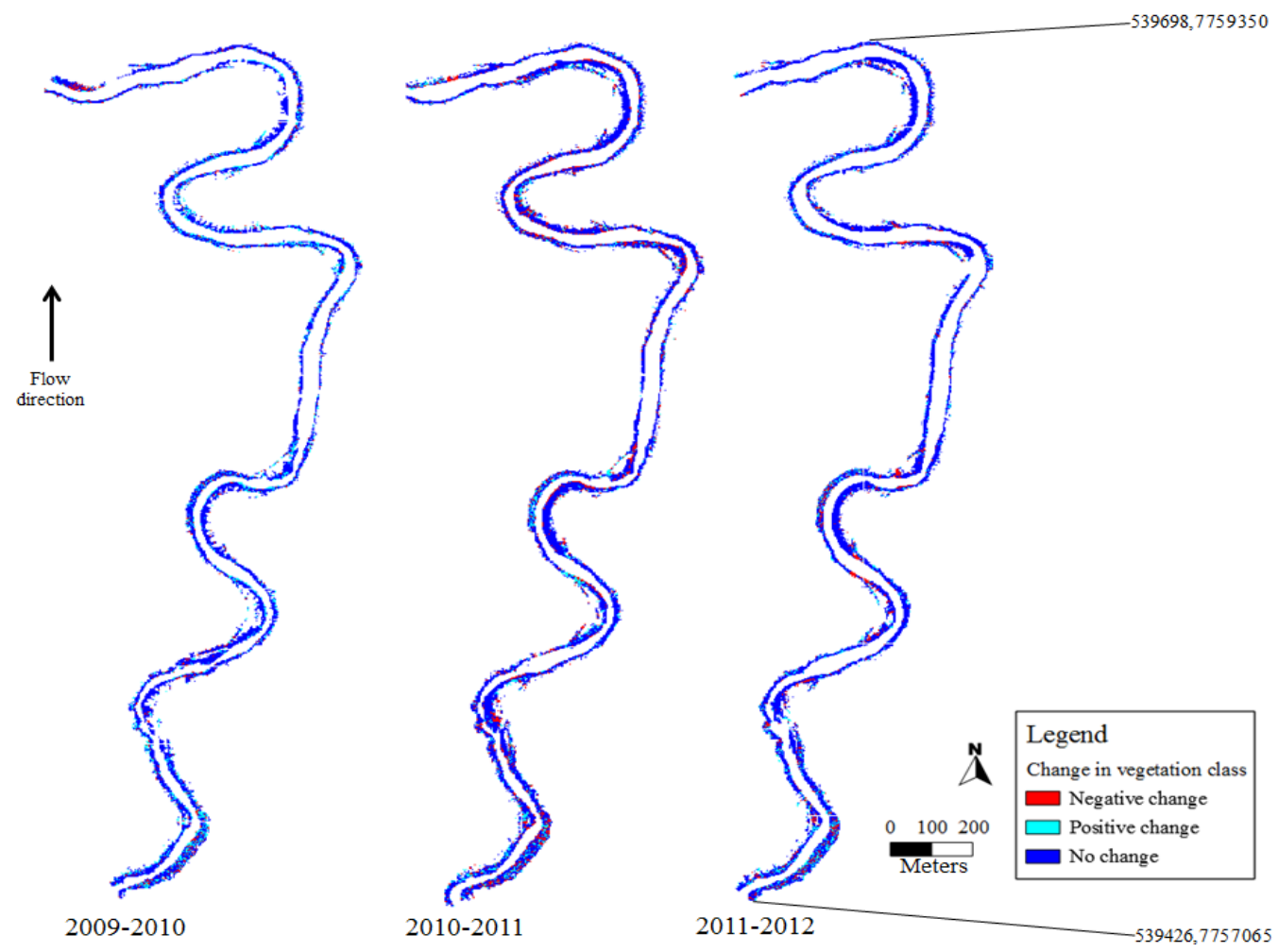

Vegetation mapping using MLS was based primarily on accurate height measurements. To normalize height, an accurate DTM is required. We obtained year-specific DTMs derived from the MLS data. MLS can provide more accurate and detailed DTMs than those of ALS in riverine environments $(c f$., $[10,17,47])$ due to the survey angle and close range. Although the survey angle is suitable for highly accurate generation of DTM of the riverbanks, it is challenging for the generation of wall-to-wall vegetation maps. MLS has a limited and varying mapping range. The theoretical mapping range is usually $\sim 100 \mathrm{~m}$; in practice, the mapping distance and data coverage vary depending on the visibility. In fluvial mapping, the area of interest is limited by definition to the riverbed. The area of interest is close to the mapping trajectory (river); thus, occlusion does not hinder mapping. Our mapping range varied from 2.5 to $32.5 \mathrm{~m}$ from the riverside, staying well within the maximum mapping range of the scanner. It is important to map the areas close to the water for modeling erosion risk. It is especially important to map vegetation in those areas that may be in continual contact with flowing water, and which also interferes with the flow field. We used a $2 \times 2 \mathrm{~m}$ grid as our 
interpretation unit. Thus, a single tree crown may contribute to multiple grid cells. Therefore this approach is not suitable for mapping vegetation density within a grid cell.

RF and NN approaches are increasingly applied for the successful classification of various vegetation characteristics [7,70-73]. Hudak et al. [71] and Latifi et al. [72] showed that the RF method is robust and flexible to predict vegetation characteristics compared with other NN methods. Thus, we chose RF as the classification method.

Wasser et al. [74] showed that riparian vegetation influenced the accuracy of canopy-height estimates based on ALS data. It can be assumed that vegetation type has an influence on the accuracy of vegetation mapping in the current study, because vegetation mapping is based on height observations from MLS data. ALS data has been used for mapping 10 classes of wetland vegetation with a classification accuracy of $82.5 \%$ [58]. Farid et al. [59] used ALS to classify three different ages of cottonwood with classification accuracy of $78 \%$. Extensive field data for ground truth were collected in these studies [58,59]. We classified four vegetation classes in the current study and obtained a similar classification accuracy of $72.6 \%$ without a need for appropriate ground truth.

Occlusion caused gaps in the DTMs. Within these gaps, vegetation cover could not be predicted because there was no information for ground height. Ground height could be interpolated to these areas, but interpolation increased uncertainty, especially in steep riverbanks. For mapping of shrub and canopy layers, this may not be a problem. However, for mapping field-layer vegetation (mean height of $7 \mathrm{~cm}$ ), it was crucial to have an accurate DTM. The field layer had the lowest classification accuracy $(35.0 \%)$ because it was misclassified as other vegetated areas. For many applications it is sufficient to determine whether or not the surface is covered by any type of vegetation. Our approach classified $20.5 \%$ of the total bare ground area as vegetated. A previous report showed that vegetation was differentiated from bare ground with accuracy greater than 98\% [60]. Our approach showed that vegetated areas were detected with very high accuracy, and misclassified only $0.7 \%$ of the vegetated area as bare ground. Vaaja et al. [16] showed that errors in DTM may affect the accuracy of vegetation classification. We used a dense DTM generated with a $20 \mathrm{~cm}$ grid. However, there were $0.5 \mathrm{~m}$ height observations in the extracted MLS metrics from steep river banks that were classified as vegetated, but were visually determined as bare ground. These kinds of errors originated in the DTM and some noise in the data, and caused some non-vegetated areas in steep riverbanks to be misclassified as vegetated. A multi-scale approach was presented that used TLS data to differentiating vegetation from bare ground [60]. This feature-based approach also could be developed to classify vegetation cover using MLS data, and it will be investigated in our future studies.

We mapped four vegetation classes. We aimed for robust MLS metrics that would not be sensitive to the viewing angle or distance to the scanner. The same metrics were then used to monitor changes in the vegetation cover. We cannot validate the classification accuracy for vegetation during 2009-2011. Our predictions for those years were made using an RF model trained with MLS data acquired in 2012. The acquisition parameters for MLS data varied from year to year, and that may have affected the classification. However, robust classification features were selected to minimize that effect. To verify the robustness of classification, we chose random samples from unchanged cells $(n=27)$ after the classification for further testing. Based on the samples for cells that belonged to the canopy layer, standard deviations for $H_{\text {mean }}, H_{s t d}$, and $H 95$ were approximately $0.5 \mathrm{~m}$. In field and shrub layers, the standard deviations within cells were approximately $0.1 \mathrm{~m}$ for all metrics. For bare ground, the 
standard deviations were less than $0.02 \mathrm{~m}$. Part of the standard deviation in vegetated grid cells originates from the natural growth of vegetation. Thus, we can assume that the selected features were not overly sensitive to the variation in MLS acquisition parameters, and that the classification accuracy for those years is close to the classification accuracy obtained with 2012 data.

Changes in vegetation can be detected at approximately the same locations where erosion or deposition has occurred. Changes are detected at the meander bends and at the straight channel sections. Lotsari et al. [64] showed that differences in erosion and deposition rates varied more between years than between different river sections during the same year. During 2009-2012 most of the straight channel sections had changes of $\pm 0.2 \mathrm{~m}$ and most of the meander bends had changes of $\pm 0.3 \mathrm{~m}$ [64]. However, some localized sites had more extreme erosion and deposition $( \pm 0.5 \mathrm{~m})$ during 2009-2012. The vegetation changes observed in meander bends were significantly larger than the error value for MLS data.

One of the main limitations in our study is the absence of actual field data for vegetation and vegetation changes during 2009-2012. Our training and validation data were measured from aerial images. Accurate field data would be required for mapping more detailed vegetation classes. Detailed field data also would be required to validate the accuracy of our vegetation monitoring, and to develop more advanced change-detection methods. However, this study proved that our approach can be used to predict vegetation classes. The consistency and precision of change estimates could not be calculated without reference data. However, it was possible to detect vegetation changes at the approximate locations where riverbank changes were reported [64]. These observations indicate that the approach could be useful for monitoring riverine vegetation. The observed trends in vegetation classes match the areas where changes (or lack of changes) were detected in the riverbanks. For example, an area that mapped as canopy layer in 2009 , and where no changes were detected, also was mapped as canopy layer in 2012. Traditionally, the main focus in fluvial research has been to measure river-related characteristics such as flow velocity, depth, and fluvial geomorphology, but not to measure vegetation. Recent field studies that include measurements of vegetation use methods such as field observations, modeling, and flume experiments [34] but not remotely sensed data. It is important to develop approaches for vegetation mapping and monitoring that exclusively use remote sensing to measure information such as height, roughness, and exact location. This information can be

incorporated into next-generation fluvial models. We assume that operational training data also could be measured visually from the MLS data instead of from aerial images.

\section{Conclusions}

This study developed and implemented an area-based approach for vegetation mapping and monitoring on riverbanks that was based on boat-mounted MLS data. Following this approach, it was possible to obtain an overall classification accuracy of $72.6 \%$ for four vegetation classes using mean height, standard deviation, and 95th-percentile of relative height. Our approach proved to be suitable for mapping and monitoring riverside vegetation. We conclude that, without specific field measurements of vegetation cover in a riverine environment, MLS data can be used to extract information for vegetation cover when it is acquired for other research purposes (e.g., to generate DTMs). In future 
studies, we will explore the use of MLS-acquired vegetation information as input data to generate more detailed fluvial models.

\section{Acknowledgments}

This study was supported by financial aid from the Academy of Finland (RivCHANGE and Roadside), the Ministry of Agriculture and Forestry (LuhaGeoIT), the Aalto Energy Efficiency Research Programme (Light Energy), and RYM Oy (Energizing Urban Ecosystems).

\section{Conflict of Interest}

The authors declare no conflict of interest.

\section{References}

1. Connor, D.J.; Loomis, R.S.; Cassman, K.G. Crop Ecology: Productivity and Management in Agricultural Systems; Cambridge University Press: Cambridge, UK, 2011; p. 351.

2. Styczen, M.E.; Morgan, R.P.C. Engineering Properties of Vegetation. In Slope Stabilization and Erosion Control: A Bioengineering Approach; Morgan, R.P.C., Rickson, R.J., Eds.; Taylor \& Francis: London, UK, 1995.

3. Beeson, C.E.; Doyle, P.F. Comparison of bank erosion at vegetated and non-vegetated channel bends. J. Am. Water Resour. Assoc. 1995, 31, 983-990.

4. Hyyppä, J.; Hyyppä, H.; Yu, X.; Kaartinen, H.; Kukko, H.; Holopainen, M. Forest Inventory Using Small-Footprint Airborne Lidar. In Topographic Laser Ranging and Scanning: Principles and Processing; Shan, J., Toth, C.K., Eds.; CRC Press: Boca Raton, FL, USA, 2008; pp. 335-370.

5. Naesset, E. Predicting forest stand characteristics with airborne scanning laser using a practical two-stage procedure and field data. Remote Sens. Environ. 2002, 80, 88-99.

6. Koch, B. Status and future of laser scanning, synthetic aperture radar and hyperspectral remote sensing data for forest biomass assessment. ISPRS J. Photogramm. Remote Sens. 2010, 65, 581-590.

7. Næsset, E.; Gobakken, T.; Holmgren, J.; Hyyppä, H.; Hyyppä, J.; Maltamo, M.; Nilsson, M.; Olsson, H.; Persson, Å.; Söderman, U. Laser scanning of forest resources: The Nordic experience. Scand. J. For. Res. 2004, 19, 482-499.

8. Vastaranta, M.; Holopainen, M.; Karjalainen, M.; Kankare, V.; Hyyppä, J.; Kaasalainen, S. TerraSAR-X stereo SAR and airborne scanning LiDAR height metrics in imputation of forest above-ground biomass and stem volume. IEEE Trans. Geosci. Remote Sens. 2013, doi: 10.1109/TGRS.2013.2248370.

9. Kankare, V.; Vastaranta, M.; Holopainen, M.; Räty, M.; Yu, X.; Hyyppä, J.; Hyyppä, H.; Alho, P.; Viitala, R. Retrieval of forest aboveground biomass and stem volume with airborne scanning LiDAR. Remote Sens. 2013, 5, 2257-2274.

10. Raumonen, P.; Kaasalainen, M.; Åkerblom, M.; Kaasalainen, S.; Kaartinen, H.; Vastaranta, M.; Holopainen, M.; Disney, M.; Lewis, P. Fast automatic precision tree models from terrestrial laser scanner data. Remote Sens. 2013, 5, 491-520. 
11. Kankare, V.; Holopainen, M.; Vastaranta, M.; Puttonen, E.; Yu, X.; Hyyppä, J.; Vaaja, M.; Hyyppä, H.; Alho, P. Individual tree biomass estimation using terrestrial laser scanning. ISPRS J. Photogramm. Remote Sens. 2013, 75, 64-75.

12. Thoma, D.P.; Gupta, S.C.; Bauer, M.E.; Kirchoff, C.E. Airborne laser scanning for riverbank erosion assessment. Remote Sens. Environ. 2005, 95, 493-501.

13. De Rose, R.C.; Basher, L.R. Measurement of river bank and cliff erosion from sequential LiDAR and historical aerial photography. Geomorphology 2011, 126, 132-147.

14. Nasermoaddeli, M.H.; Pasche, E. Application of Terrestrial 3D Laser Scanner in Quantification of the Riverbank Erosion and Deposition. In Proceedings of International Conference on Fluvial Hydraulics (Riverflow 2008), Cesme-Ismir, Turkey, 3-5 September 2008; Volume 3, pp. 2407-2416.

15. Resop, J.P.; Hession, W.C. Terrestrial laser scanning for monitoring streambank retreat: Comparison with traditional surveying techniques. J. Hydraul. Eng. 2010, 136, 794-798.

16. Vaaja, M.; Hyyppä, J.; Kukko, A.; Kaartinen, H.; Hyyppä, H.; Alho, P. Mapping topography changes and elevation accuracies using a mobile laser scanner. Remote Sens. 2011, 3, 587-600.

17. O’Neal, M.A.; Pizzuto, J.E. The rates and spatial patterns of annual riverbank erosion revealed through terrestrial laser-scanner surveys of the Sourth River, Virginia. Earth Surf. Process. Landf. 2011, 36, 695-701.

18. Kasvi, E.; Vaaja, M.; Petteri, A.; Hyyppä, H.; Hyyppä, J.; Kaartinen, H.; Kukko, A. Morphological changes on meander point bars associated with flow structure at different discharges. Earth Surf. Process. Landf. 2013, 38, 577-590.

19. Alho, P.; Kukko, A.; Hyyppa, H.; Kaartinen, H.; Hyyppä, J.; Jaakkola, A. Application of boat-based laser river survey. Earth Surf. Process. Landf. 2009, 34, 1831-1838.

20. Barber, D.M.; Mills, J.P. Vehicle Based Waveform Laser Scanning in a Coastal Environment. In Proceedings of the 5th International Symposium on Mobile Mapping Technology, Pradua, Italy, 29-31 May 2007.

21. Bitenc, M.; Lindenbergh, R.; Khoshelham, K.; van Waarden, A.P. Evaluation of a LiDAR land-based mobile mapping system for monitoring sandy coasts. Remote Sens. 2011, 3, 1472-1491.

22. Kukko, A.; Kaartinen, H.; Hyyppä, J.; Chen, Y. Multiplatform mobile laser scanning: Usability and performance. Sensors 2012, 12, 11712-11733.

23. Glennie, C.; Brooks, B.; Ericksen, T.; Hauser, D.; Hudnut, K.; Foster, J.; Avery, J. Compact multipurpose mobile laser scanning system - Initial tests and results. Remote Sens. 2013, 5, 521-538.

24. Graham, L. Mobile mapping systems overview. Photogramm. Eng. Remote Sens. 2010, 76, 222-228.

25. Petrie, G. Mobile mapping systems: An introduction to the technology. GeoInformatics 2010, 13, 32-43.

26. Simon, A.; Curini, A.; Darby, S.E.; Langedoen, E.J. Bank and near-bank processes in an incised channel. Geomorphology 2000, 35, 193-217.

27. Rinaldi, M.; Darby, S.E. Modelling River-Bank-Erosion Processes and Mass Failure Mechanisms: Progress towards Fully Coupled Simulations. In Gravel-Bed Rivers VI: From Process Understanding to River Restoration; Habersack, H., Piégay, H., Rinaldi, M., Elsevier B.V., Eds.; Elsevier Science Publishing Company: Oxford, UK, 2008; pp. 213-239.

28. Parker, C.; Simon, A.; Thorne, C.R. The effects of variability in bank material properties on riverbank stability: Goodwin Creek, Mississippi. Geomorphology 2011, 101, 533-543. 
29. Motta, D.; Abad, J.D.; Langedoen, E.J.; Garcia, M.H. A simplified 2D model for meander migration with physically-based bank evolution. Geomorphology 2012, 163-164, 10-25.

30. Millar, R.G. Influence of bank vegetation on alluvial channel patterns. Water Resour. Res. 2000, 36, 1109-1118.

31. Smith, D.G. Effect of vegetation on lateral migration of anastomosed channels of a glacier meltwater river. Geol. Soc. Am. Bull. 1976, 87, 857-860.

32. Wynn, T.M. The Effects of Vegetation on Stream Bank Erosion. Ph.D. Dissertation, Virginia Polytechnic Institute and State University, Blacksburg, VA, USA, 14 May 2004.

33. Wynn, T.M.; Mostaghimi, S. The effects of vegetation and soil type on stream bank erosion, Southwestern Virginia, USA. J. Am. Water Resour. Assoc. 2006, 42, 69-82.

34. Gurnell, A. Plants as river system engineers. Earth Surf. Process. Landf. 2013, doi: 10.1002/esp.3397.

35. Camporeale, C.; Ridolfi, L. Riparian vegetation distribution induced by river flow variability: A stochastic approach. Water Resour. Res. 2006, doi: 10.1029/2006WR004933.

36. Pollen-Bankhead, N.; Simon, A.; Jaeger, K.; Wohl, E. Destabilization of streambanks by removal of invasive species in Canyon de Chelly National Monument, Arizona. Geomorphology 2009, 103, 363-374.

37. Chanson, H. The Hydraulics of Open Channel Flow-An Introduction; Butterworth Heinemann: Oxford, UK, 1999; p. 495.

38. Hunter, N.M.; Bates, P.D.; Horrit, M.S.; Wilson, M.D. Simple spatially-distributed models for predicting flood inundation: A review. Geomorphology 2007, 90, 208-225.

39. Midgley, T.L.; Fox, G.A.; Heeren, D.M. Evaluation of the bank stability and toe erosion model (BSTEM) for predicting lateral retreat on composite streambanks. Geomorphology 2012, 145-146, 107-114.

40. Horrit, M.; Bates, P. Evaluation of $1 \mathrm{D}$ and 2D numerical models for predicting river flood inundation. J. Hydrol. 2002, 268, 87-99.

41. Pasternack, G B.; Gilbert, A.T.; Wheaton, J.M.; Buckland, E.M. Error propagation for velocity and shear stress prediction using 2D models for environmental management. J. Hydrol. 2006, $328,227-241$.

42. McMillan, H.K.; Brasington, J. Reduced complexity strategies for modelling urban flood-plain inundation. Geomorphology 2007, 90, 226-243.

43. Pender, G.; Néelz, S. Use of computer models of flood inundation to facilitate communication in flood risk management. Environ. Hazard. 2007, 7, 106-114.

44. Koivumäki, L.; Alho, P.; Lotsari, E.; Käyhkö, J.; Saari, A.; Hyyppä, H. Uncertainties in flood risk mapping: A case study on estimating building damages for a river flood in Finland. J. Flood Risk Manag. 2010, 3, 166-183.

45. Kasvi, E.; Alho, P.; Vaaja, M.; Hyyppä, H.; Hyyppä, J. Spatial and temporal distribution of fluvio-morphological processes on a meander point bar during a flood event. Hydrol. Res. 2013, doi: 10.2166/nh.2013.091.

46. Lotsari, E.; Wainwright, D.; Corner, G.D.; Alho, P.; Käyhkö, J. Surveyed and modelled one-year morphodynamics in the braided lower Tana River. Hydrol. Process. 2013, doi: 10.1002/hyp.9750. 
47. Alho, P.; Vaaja, M.; Kukko, A.; Kasvi, E.; Kurkela, M.; Hyyppä, J.; Hyyppä, H.; Kaartinen, H. Mobile laser scanning in fluvial geomorphology: Mapping and change detection of point bars. Z. Geomorphol. Suppl. Issue. 2011, 55, 31-50.

48. Hohental, J.; Alho, P.; Hyyppä, J.; Hyyppä, H. Laser scanning applications in fluvial studies. Progr. Phys.Geogr. 2011, 35, 782-809.

49. Jaakkola, A.; Hyyppä, J.; Hyyppä, H.; Kukko, A. Retrieval algorithms for road surface modelling using laser-based mobile mapping. Sensors 2008, 8, 5238-5249.

50. Kukko, A. Road Environment Mapper-3D Data Capturing with Mobile Mapping. Licentiate's Thesis, Helsinki University of Technology, Espoo, Finland, 17 September 2009.

51. Goulette, F.; Nashashibi, F.; Abuhadrous, I.; Ammoun, S.; Laurgeau, C. An Integrated On-board Laser Range Sensing System for On-the-Way City and Road Modelling. In Proceedings of the ISPRS Commission I Symposium-From Sensors to Imagery, Paris, France, 3-5 July 2006; pp. 43:1-43:6.

52. Jochem, A.; Höfle, B.; Rutzinger, M. Extraction of vertical walls from mobile laser scanning 441 data for solar potentiaL Assessment. Remote Sens. 2011, 3, 650-667.

53. Wu, B.; Yu, B.; Yue, W.; Shu, S.; Tan, W.; Hu, C.; Huang, Y.; Wu, J.; Liu, H. A voxel-based method for automated identification and morphological parameters estimation of individual street trees from mobile laser scanning data. Remote Sens. 2013, 5, 584-611.

54. Wang, Y.; Liang, X.; Flener, C.; Kukko, A.; Kaartinen, H.; Kurkela, M.; Vaaja, M.; Hyyppä, H.; Alho, P. 3D modeling of coarse fluvial sediments based on mobile laser scanning data. Remote Sens. 2013, 5, 4571-4592.

55. Holopainen, M.; Vastaranta, M.; Kankare, V.; Hyyppä, J.; Liang, X.; Litkey, P.; Yu, X.; Kaartinen, H.; Kukko, A.; Kaasalainen, S.; et al. The use of ALS, TLS and VLS Measurements in Mapping and Monitoring Urban Trees. In Proceedings of Joint Urban Remote Sensing Event, JURSE, Munich, Germany, 11-13 April 2011; doi: 10.1109/JURSE.2011.5764711.

56. Holopainen, M.; Kankare, V.; Vastaranta, M.; Liang, X.; Lin, Y.; Vaaja, M.; Yu, X.; Hyyppä, J.; Hyyppä, H.; Kaartinen, H.; et al. Urban tree mapping with airborne, terrestrial, and mobile laser scanning. Urban For. Urban Green. 2013, in press.

57. Jaakkola, A.; Hyyppä, J.; Kukko, A.; Yu, X.; Kaartinen, H.; Lehtomäki, M.; Lin, Y. A low-cost multi-sensoral mobile mapping system and its feasibility for tree measurements. ISPRS J. Photogramm. Remote Sens. 2010, 65, 514-522.

58. Zlinszky, A.; Mücke, W.; Lehner, H.; Briese, A.; Pfeifer, N. Categorizing wetland vegetation by airborne laser scanning on Lake Balaton and Kis-Balaton, Hungary. Remote Sens. 2012, 4, 1617-1650.

59. Farid, A.; Rautenkranz, D.; Goodrich, D.C.; Marsh, S.E.; Sorooshian, S. Riparian vegetation classification from airborne laser scanning data with an emphasis on cottonwood trees. Can. J. Remote Sens. 2006, 32, 15-18.

60. Brodu, N.; Lague, D. 3D terrestrial lidar data classification of complex natural scenes using a multi-scale dimensionality criterion: Application in geomorphology. ISPRS J. Photogramm. Remote Sens. 2012, 68, 121-134. 
61. Kukko, A.; Andrei, C.-O.; Salminen, V.-M.; Kaartinen, H.; Chen, Y.; Rönnholm, P.; Hyyppä, H.; Hyyppä, J.; Chen, R.; Haggrén, H.; et al. Road Environment Mapping System of the Finnish Geodetic Institute-FGI ROAMER. In Proceedings of ISPRS Workshop on Laser Scanning 2007 and (SilviLaser 2007), Espoo, Finland, 12-14 September 2007; Volume 36, pp. 241-247.

62. Kaartinen, H.; Hyyppä, J.; Kukko, A.; Jaakkola, A.; Hyyppä, H. Benchmarking the performance of mobile laser scanning systems using a permanent test field. Sensors 2012, 12, 12814-12835.

63. Axelsson, P. DEM Generation from Laser Scanner Data Using Adaptive TIN Models. In Proceedings of XIX ISPRS Congress, Amsterdam, The Netherlands, 16-22 July 2000; Volume 33, pp. 110-117.

64. Lotsari, E.; Vaaja, M.; Flener, C.; Kaartinen, H.; Kukko, A.; Kasvi, E.; Hyyppä, H.; Hyyppä, J.; Alho, P. Annual bank and point bar morphodynamics of a meandering river based on high-accuracy multi-temporal laser scanning and flow data. Water Resour. Res. 2013, under review.

65. McGaughey, R.J. FUSION/LDV: Software for LiDAR Data Analysis and Visualization, FUSION Version 3.30; February 2013. Available online: http://forsys.cfr.washington.edu/fusion/ FUSION_manual.pdf (accessed on 11 April 2013).

66. Breiman, L. Random forests. Mach. Learn 2001, 45, 5-32.

67. Jothityangkoon, C.; Sivapalan, M. Towards estimation of extreme floods: Examination of the roles of runoff process changes and floodplain flows. J. Hydrol. 2003, 281, 206-229.

68. Makaste, B.; Maas, G.J.; van den Brink, C.; Wolfert, H.P. The influence of floodplain vegetation succession on hydraulic roughness: Is ecosystem rehabilitation in dutch embanked floodplains compatible with flood safety standards? Ambio 2011, 40, 370-376.

69. Rinaldi, M.; Mengoni, B.; Luppi, L.; Darby, S.E.; Mosselman, E. Numerical simulation of hydrodynamics and bank erosion in a river bend. Water Resour. Res. 2008, 44, 1-17.

70. Yu, X.; Hyyppä, J.; Vastaranta, M.; Holopainen, M. Predicting individual tree attributes from airborne laser point clouds based on random forest technique. ISPRS J. Photogramm. Remote Sens. 2011, 66, 28-37.

71. Hudak, A.; Crookston, N.; Evans, J.; Hall, D.; Falkowski, M. Nearest neighbor imputation of species-level, plot-scale forest structure attributes from LiDAR data. Remote Sens. Environ. 2008, 112, 2232-2245

72. Latifi, H.; Nothdurft, A.; Koch, B. Non-parametric prediction and mapping of standing timber volume and biomass in a temperate forest: Application of multiple optical/LiDAR-Derived predictors. Forestry 2010, 83, 395-407

73. Falkowski, M.; Hudak, A.; Crookston, N.; Gessler, P.; Smith, A. Landscape-scale parameterization of a tree-level forest growth model: A k-NN imputation approach incorporating LiDAR data. Can. J. Forest Res. 2010, 40, 184-199

74. Wasser, L.; Day, R.; Chasmer, L.; Taylor, A. Influence of vegetation structure on lidar-derived canopy height and fractional cover in forested riparian buffers during leaf-off and leaf-on conditions. PLoS One 2013, 8, e54776.

(C) 2013 by the authors; licensee MDPI, Basel, Switzerland. This article is an open access article distributed under the terms and conditions of the Creative Commons Attribution license (http://creativecommons.org/licenses/by/3.0/). 